\title{
GEOHERITAGE AND GEOTOURISM IN THE REPUBLIC OF MACEDONIA
}

\author{
DOI: http://dx.doi.org/10.18509/GBP.2018.12
}

UDC: $338.483 .11: 551.4(497.7)$

\section{Anita Todorova \\ Dragan Kolchakovski \\ Olgica Dimitrovska}

University of "Ss Cyril and Methodius"-Skopje, Faculty of natural sciences and mathematics, Institute of geography, Skopje, Republic of Macedonia

\begin{abstract}
Nature has always attracted people with the beauty it creates. However, for the natural potential of a certain territory to be appropriately used, nature should be valorized, geoconservation and sustainable development. Attractive geodiversity is the main source for the development of geo-tourism. The promotion of geo-tourist destinations raises public awareness of the values of the objects of the geoheritage, but also of their endangerment. From the aspect of the geoheritage of Republic of Macedonia's territory, it can be noticed that there are representative and rare geological and geomorphologic objects which are a significant factor for the development of the geotourism. The objects of the geoheritage in the Republic of Macedonia possess high values and attractiveness that can be interpreted, edited and promoted for geo-territorial purposes. This study discusses the potential of Macedonia's geoheritage, which is based on preserving and managing the landscape and on the connection with the potential of its geotourism.
\end{abstract}

Keywords: geoheritage, geotourism, potential, geoconservation

\section{INTRODUCTION}

Nature always attracts people with its beauty that it creates. All occurrences and forms of inanimate nature differ in their diversity. Geodiversity can be defined simply as "the natural range (diversity) of geological (rock, minerals, fossils), geomorphological (land form, physical processes) and soil features. It includes their assemblages, relationships, properties, interpretations and systems" [3]. The phenomena and forms of geodiversity that are of great importance for man represent the geoheritage. Geoheritage comprises those elements of natural geodiversity which are of significant value to humans for nondepleting purposes, which do not decrease their intrinsic or ecological values [12]. Geoheritage may have esthetic values; economic values; functional values (such as soils and ecosystem functions) and research and education values [3]. The economic value of the geoheritage can be interpreted through various forms of tourism, that is, through geotourism. The objects of geoheritage are an example of exceptional geological, geomorphologic, pedological and archaeological significance, which in recent years have been used as a means of developing geo-tourist destinations. Geotourism is based on the values of abiotic environment. Specifically, the basis of this selective form of tourism is geodiversity. Geotourism is a form of natural area tourism that specifically focuses on geology and landscape. It promotes tourism to geosites and conservation of geo-diversity and understanding of earth sciences through appreciation and learning. This is achieved through independent visits to geological features, use of geo-trails and viewpoints, guided 
tours, geoactivities and patronage of geosite visitor centers [10]. There are five basic principles that are fundamental to geotourism. These are: the geologically based, sustainable, geologically informative (geo-interpretation), locally beneficial and tourist satisfaction [2]. Geotourism must be based on a geological base (it is thought of objects of geoheritage). A major challenge for geotourism is to keep a close watch on the sustainable use of the objects of geoheritage, to avoid destroying natural values. Geotourism attracts people who want to interact with nature, all in order to expand their knowledge. Education during a visit to a (geo) tourist destination is called an interpretation and it is an essential component of the experience of visitors to tourist destinations [4]. The interpretation is a vital part of the way people perceive the place of their visit. The geotourist's interpretation allows him to reach a link with the destination through knowledge and understanding. It can be represented by guiding tours and hiking, interpretive and information boards, published guides, brochures, leaflets, other printed materials and through information centers (lectures and audiovisual presentations) [1]. Local communities can be involved in geotourism by providing services and disseminating knowledge. There are several types of geotourists who consciously or unconsciously are interested in the phenomena of geotourism. Geotourism can be defined, but it's harder to define who and what is a geotourist? Grant through Dowling has suggested that there is a spectrum of geotourists from general 'visitors' who are either unknown, aware of interested in geological tourism, to 'geo' tourists ranging from geoamateurs to geo-specialists to geoexperts [2]. The connection of geotourism with cultural tourism can be represented through the exploitation of geological resources that is through some kind of art or cultural significance of the rocks and relief forms. The anthropological and paleontological resources can be included in the geotourism offers. The geological and geomorphological characteristics are the basic resources for developing adventurous activities in nature. Such are mountaineering, alpine climbing and certain extreme sports. Geotourism can be combined with other tourist offers of cultural and historical significance. Any object of geoheritage may be endangered by visitors by improper use. Therefore, a geoconservation should be carried out to maintain important representative phenomena and processes of geodiversity, such as rocks, landscapes, soil features, and more. The conservation refers to the protection and management of natural values. Promoting the geotourism destinations raises the public awareness of the values of the objects oaf the geoheritage, but also of their endangerment.

By developing geotourism in one state, natural values are promoted which generate economic benefits from an one side, and on the other hand they should be adequately protected and provided for sustainable use.

\section{PURPOSE OF THE STUDY}

The geological structure and the development of the Earth's crust on the territory of the Republic of Macedonia through the geological history, combined with the influence of the exogenous factors, contributed to the development of interesting and varied elements of geodiversity. Although the Republic of Macedonia occupies a relatively small area of $25713 \mathrm{~km}^{2}$, it possesses numerous geological, geomorphological and hydrological relief forms, which, because of their diversity and uniqueness, exceed the national significance and reach a global level of significance. These geo-valuations deserve to be treated with an adequate degree of protection, their promotion and sustainable use. In the past decades, the priority in all countries in the world is the conservation and promotion of the objects 
of geoheritage and their sustainable exploitation. The various natural conditions have contributed to the Republic of Macedonia being one of the few countries in Europe that has a diverse and specific nature. In the past period, several institutions and researchers have proposed to protect important geological, geomorphological and hydrological phenomena and shapes. Some of them are included in the Spatial Plan of the Republic of Macedonia, and some are protected by legal acts.

The current state of the number of protected areas in the Republic of Macedonia is 86 objects or $8.93 \%$ with a total area of 229719.07 ha [13]. According to the Spatial Plan of the Republic of Macedonia for the period 2002-2020, through various degrees of protection until 2020, it is planned to protect another 193 sites and objects of nature. The total area of all protected areas, until 2020 , is 296,963 ha or $11,5 \%$ of the total territory of the Republic of Macedonia [5]. In the study on protection of geodiversity and geoheritage in the Republic of Macedonia and other components of nature (biological and landscape diversity, 23 most important areas for protection have been identified [14]. As a result, the Republic of Macedonia has numerous objects of geoheritage with high values and attractiveness that can be adequately interpreted, arranged and promoted for geotouristic purposes. Of the protected and proposed objects of geoheritage, only a small part is used as geotourism destinations. Geological, geomorphological and hydrological values represent a potential area for the development of geotourism. The objects of geoheritage can be used to enrich tourist offers on a local and regional level. They possess scientific, ambiental, educational, economic, functional and cultural values that need to be promoted and interpreted in the function of geotourism.

In this paper, three objects of geoheritage will be processed, which differ in their way of genesis, their degree of protection, the manner of presentation and their potential for geotourism. The monument of nature "Vevchani Springs" is protected by law, touristically arranged and known to domestic and foreign tourists. There is also a lot of tourist potential in the other two objects: the gorge Peshti and the "Pillow lava" site, which can be promoted with a suitable presentation and to become a desired tourist destination. With an appropriate presentation of these facilities has made an attempt to show that the Republic of Macedonia owns objects that are on the list of national importance and undiscovered primitive wealth that possesses great tourist potential.

\section{SITES WHICH ARE SUITABLE FOR GEOTOURSM DEVELOPMENT}

The three facilities from the genesis have representative and rare relief forms, different protection status and great potential for the development of geotourism.

The monument of nature "Vevchani Springs" is located the eastern slopes of Mount Jablanica, near the village of Vevchani. The "Vevchani Springs" are karst aquifer, whose waters break out from the cracks located from the top down the line 100 meters long and with a difference of 10 meters. They are composed of seven smaller springs that comprise and comprise the course of the Matica River or Vevchanska River. The main spring is located in the opening of a cave. A dozen meters below the water comes from several permanent springs that communicate underground with the main spring. The cave was researched in the length of about $40 \mathrm{~m}$. According to several years of measuring of Vevchani Springs, the average flow is around $15001 /$ sec. [6]. Above the Vevchani Springs, on the upper border of the site ridges can be seen, valleys, dolines, uvala and other geomorphological objects. The whole area is characterized by a distinctive natural beauty and attractiveness, that is, the area surrounding the springs abounds with many 
plant and animal species. All these characteristics make the site of "Vevchani Springs" in 2012 to be declared in the category of monument of nature [11]. The total area of the protected area "Vevchani Springs" is 1370 hectares [11]. The "Vevchani Springs" are characterized by a favorable location because they are located in the immediate vicinity of the village of Vevchani. With the very accessible location of the springs, they can be used for recreation by tourists and for scientific research by a large number of students, and scientists. "Vevchani Springs" are regulated by the Municipality of Vevchani. "Vevchani Springs" can be reached through four entrances. There is one main entrance, which is about $235 \mathrm{~m}$ long. Natural materials were used for the arrangement of the "Vevchani Springs", which would not disturb the natural ambience of the site. The paths are made of stone and enclosed by a protective wooden fence leading to the main spring of "Vevchani Springs". Throughout the paths there are wooden boards showing the direction of the Vevchani Springs, and there are also other boards showing the hiking trails to Crn Vrv and the village of Gorna Belica. In several places there are wooden benches and tables where visitors can rest and feel the water bubbling and the deep shade under the beech forest. For additional information there is an information (interpretive) panel that provides more detailed information about the history of the Vevchani Springs, the locality as a monument of nature and the present flora and fauna within the boundaries of the protected area. Throughout the paths lighting is set where you can enjoy the beauty of the springs at nighttime too. Vevchani Springs are famous and quite attractive. They are also presented on many web pages and in various tourist brochures. Many tourists come from both our country and abroad to see the natural values. Vevchani Springs can be inserted into the tourist tour during the visit to Ohrid and Struga. Also, many tourists are attracted and visit the springs during the holiday Vasilica (Old New Year) where the well-known Vevchani Carnival is being organized. Other tourist activities include hiking, horse riding, rural tourism, mountain biking, hunting and fishing, trekking, speleological tourism, alpinism and others. Restaurants, hotels and holiday homes have been built and more are being built to provide services for tourists.

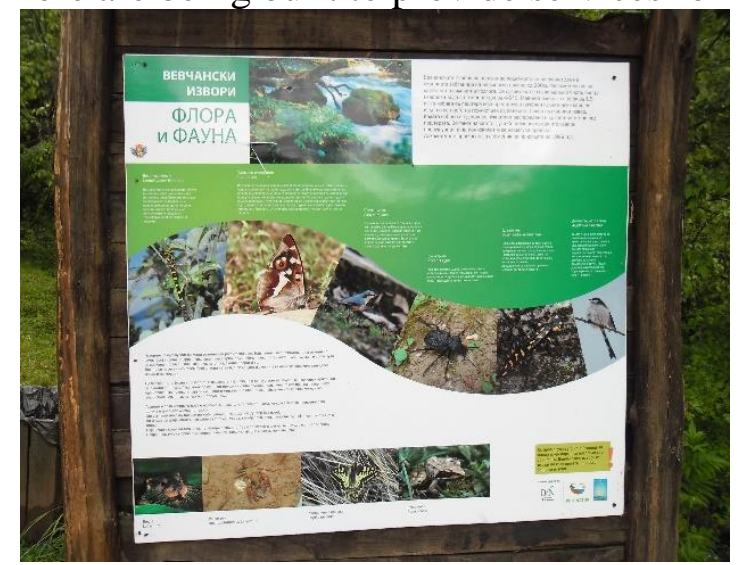

Figure 1. Interpretive panel, "Vevchani Springs"

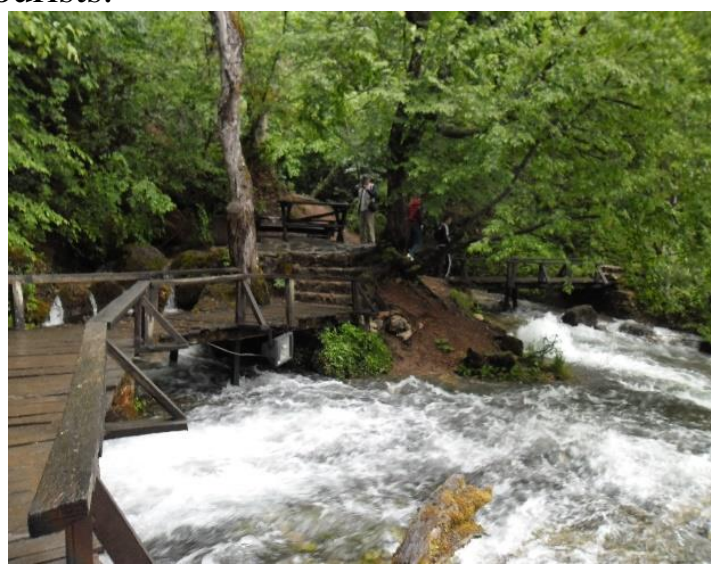

Figure 2. The natural ambiance of the "Vevchani Springs"

Photo: Todorova

The gorge Peshti is located in the central part of the Republic of Macedonia, south of the city of Veles. It lies near the mouth of the river Babuna into Vardar, at an altitude of 300$350 \mathrm{~m}$. This gorge got its name from the fact that there are many caves throughout on both sides of the gorge, which represent more characteristic and almost unique karst underground forms in this area. The river Babuna with mild meandering through the field 
of Makarovec flows into the Vardar. The river's water deeply cuts the thick layers of the Mesozoic limestone with Cretaceous old age where the gorge Peshti was formed. The gorge Peshti is about $500 \mathrm{~m}$ long [8]. In the gorge itself there are many caves that differ in size, complexity of channels, accessibility, paleontological findings, etc. Distinct caves are: Makarovec cave, Monashka cave, Ponor cave, Crkvice cave and others.

The Ponor cave is located on the west side of the gorge at a height of $138 \mathrm{~m}$. The entrance of the cave is horizontal, but then the channel is vertical. The cave is built from highly degraded underground channels extending deep inside the carbonate mass. It is filled with cave jewelry [9]. At about $90 \mathrm{~m}$ above the river bed of the river Babuna near the entrance to the gorge there is a smaller cave called "Crkviche". The total explored length is $21 \mathrm{~m}$. The channel of this cave is composed of three plunge pools. In the entrance of the cave there are remains of frescoes that prove that once this cave was a refuge for the monks. The cave is built with an underground independent stream that flows underground into the river Babuna [9]. On the right side of the gorge there is the entrance of the Monashka cave. It was named after the remains of frescoes found in it. It is a small cave built in the vertical layers of the gorge Peshti. Under the entrance to the cave there is a good part 1.5 $m$ deep, built from the flow of water that descends from the canal [9]. The cave Makarovec is located on the right valley side of the Babuna river. The opening and entrance of the cave are at a height of $110 \mathrm{~m}$ above the river bed of Babuna at an altitude of $300 \mathrm{~m}$. The entrance to the cave has a kidney shape, wide $8.70 \mathrm{~m}$, and $6 \mathrm{~m}$ high. At the bottom of the main channel and in the wide hall there are stalagmites, most of which were destroyed and covered with sediments [9]. In the cave Makarovec Manakovic discovered for the first time the artifacts of the prehistoric man (the artifacts resemble buttons, scrapers and various blades) and fossils of cave animals in the wide hall that were of Pleistocene age [9]. The fossil remains found in the cave Makarovec were investigated by the curator Risto Garevski, who found that there were remnants of cave bear (Ursus spelaeus, Rosenmuller, 1794), cave lion (Panthera spelaea, Goldfuuss, 1810), panther or leopard (Panthera Pardus, Linnaeus, 1758), wolf (Canis lupus, Linnaeus, 1758), fox (Vulpes vulpes crucigera, Bechstein, 1789), cave hyena (Crocuta spelaea), horse species (Equus caballus, Linnaeus, 1758) and very few fossil remains have been found by wild donkey (Equus hydruntinus), Capricorn (Capra ibex, Linnaeus, 1758) and others.

With the legislation, the горге Peshti is proposed to be protected as a SNR (strict natural reserve). Within the gorge proposed for protection is the cave Makarovec as a monument of nature.

Due to the proximity of the city of Veles, most often in the summer months, it is visited by a large number of visitors who use it as a picnic and recreational place. Many lovers of mountaineering, speleologists, recreationists, nature lovers visit the gorge. There is no road built up to the gorge. The current arrangement of the gorge is that it is not arranged for visitors, but only in certain locations in the most inaccessible places, improvised iron stairs are made so the gorge can be reached to. It is necessary to arrange a path to the gorge and to set up an informative panel that will explain the origin of the gorge Peshti and the caves. For cave enthusiasts a separate informative panel has to be made with the exact location of the larger caves that can be adapted for visiting. On the vertical valley sides certain alpinistic trails need to be made in order to protect the rest of the gorge. It is interesting to mention that the caves can be made to be an interesting attraction for speleo tourism, because the remains of the frescoes can be seen in the caves of "Crkviche" and "Monashka". The most interesting and attractive for visiting is the "Makarovec" cave where models of the fossil remains of the mammals that lived here or the real image of 
the then living world can be made. The gorge Peshti is mentioned in journals and magazines, and it is also promoted on the website of the Municipality of Veles. According to the position and size of the space, the configuration of the terrain, the natural conditions and amenities, the presented contents and values, the gorge Peshti offers conditions for various tourist activities. Such are: trekking, picnics, hunting and fishing tourism, speleological tourism, alpinism, etc.

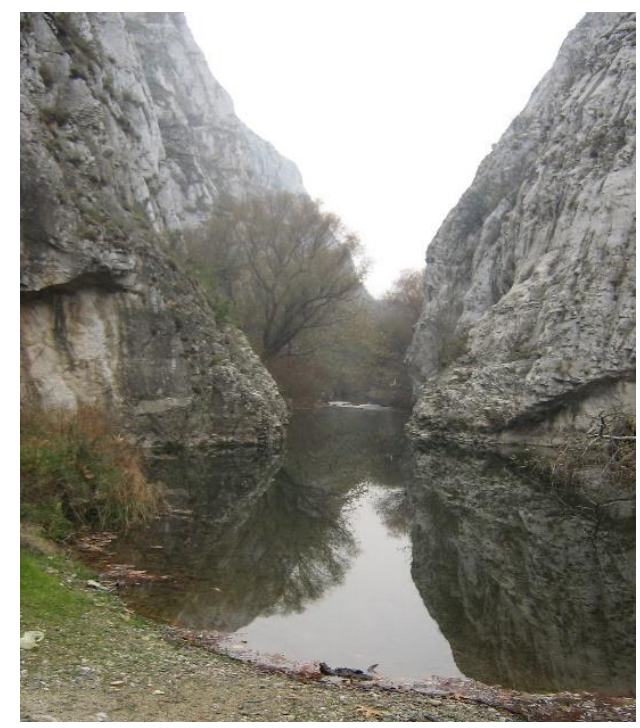

Figure 3. The gorge Peshti

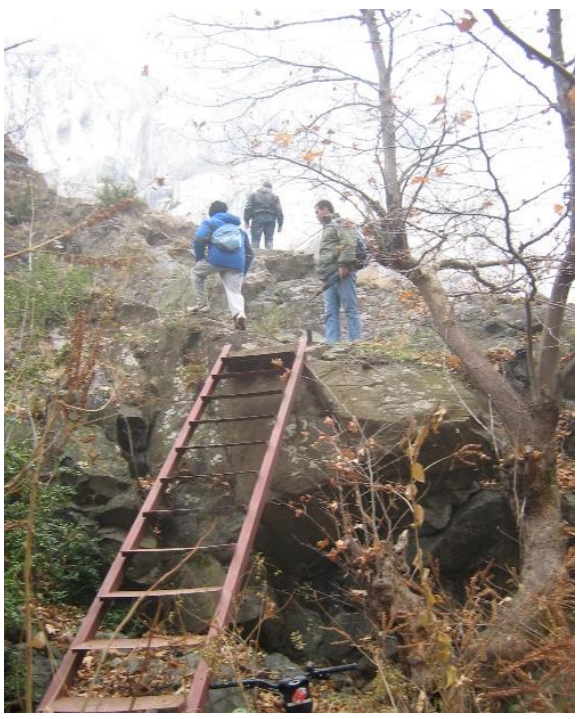

Figure 4. The improvised iron stairs at the gorge Peshti

Photo: Todorva

The site of "Pillow Lava" is located southwest of the village of Miravci. It covers the eastern slopes of the mountain Kozuf, at $185 \mathrm{~m}$ above sea level. At the inflow of Stara Reka into the river Petrushka, i,e. at the connection itself, both rivers have created small gorges with canyon characteristics which are $13 \mathrm{~m}$ height. Through the course of Stara River, the unequal crossing form three cascades and two waterfalls with $500 \mathrm{~m}$ distance between them. The first cascade has a length of 9,2 $\mathrm{m}$ and has formed a plunge pool at the bottom. The plunge pool is $11 \mathrm{~m}$ wide and $3 \mathrm{~m}$ deep (according to the field measurements done on the 17/04/2016). It has a well-like depression and its walls are smooth, almost polished, while the presence of gravel material noticeable on its bottom. Down the river with $30 \mathrm{~m}$ distance from the first cascade, a second cascade is formed with a length of $8.2 \mathrm{~m}$. After him there is another cascade with a length of $3.3 \mathrm{~m}$. Immediately after the three cascades at a distance of $8 \mathrm{~m}$, a waterfall with a height of 5.3 $\mathrm{m}$ was formed. A few meters downstream of the river there is a second waterfall with a height of $7 \mathrm{~m}$. On its bottom there is a plunge pool, which, in contrast to the first one, is larger and has a width of $10 \mathrm{~m}$, a length of $13 \mathrm{~m}$ and a depth of $4 \mathrm{~m}$ (according to field measurements done on the 17/04/2016) [15]. This is where the appearance of the "pillow lava" or magmatites (spillites), which as a result of the Triassic-Jurassic magmatism are cast in the aquatic environment, and due to the fluvial erosion of Stara Reka and Petrushka Reka, these occurrences begin to be visible on the surface of the terrain [7]. The small gorges with canyon characteristics with the plunge pools, cascades, waterfalls and the appearance of pillow lava, even though they occupy a relatively small area, make this site quite attractive and appealing. According to the field observations, it is recommended that this site be protected as soon as possible. The attractions offered by this site can be seen 
on-site and are partially arranged for visitors. On the space around the first plunge pool, there is a catering facility that works only in the summer. During the construction of the catering facility, materials from wood and iron were used, which violate the natural ambient. It is necessary to lay wooden benches and trash cans, and at the same time to set up an informative panel that would describe the way of forming the "pillow lava", the plunge pools and the Stara Reka canyon. The second plunge pool, the cascades and the waterfalls are not regulated by man at all. In this space you can arrange a path that would lead to the second plunge pool, which will be made of natural materials that would not disturb the natural ambience. Around the second plunge pool the terrain must be properly cleaned and wooden benches to be set, also tables and trash cans. On the local road that passes to the site, it is necessary to set up a road sign which will indicate where the site is located. In this area recreational and picnic tourism can be developed, but it is also very suitable for trekking, hunting and fishing tourism and others. There is little that is known about this area in the electronic and written media. Some of the magmatic rocks/spilites that have a circular shape can be exhibited in the Natural Science Museum of the Republic of Macedonia in Skopje with the aim of better acquainting them about their appearance and volcanic activity that took place on the territory of the Republic of Macedonia.

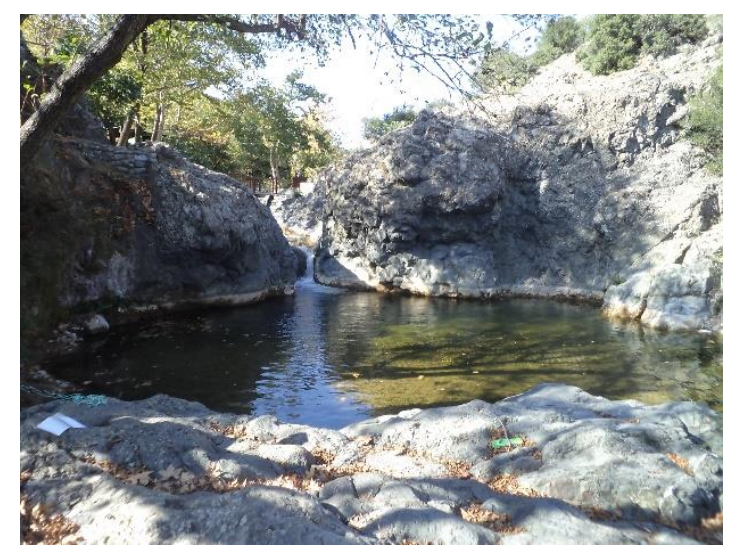

Figure 5. The first plunge pool

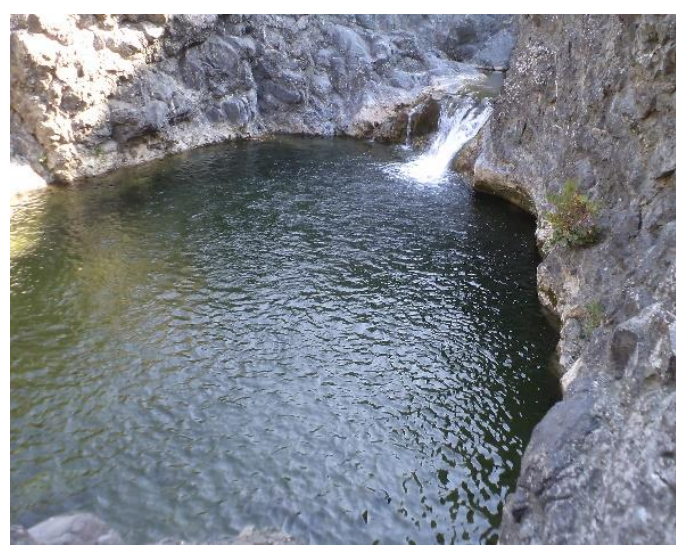

Figure 6. The second plunge pool

Photo: Todorova

\section{DISCUSSION AND CONCLUSION}

It can be said that the abiotic environment attracted people from a very long time ago, but over the last few years, geotourism has great significance, as it becomes more attractive. This is due to the great promotion of geotourism because it awakens the interests of people about newly discovered phenomena and forms. Tourism is an important instigator of economic development in the Republic of Macedonia, but the potential for the development of geotourism has not yet been fully exploited. In comparison with the European countries, the Republic of Macedonia is lagging behind in terms of promoting the objects of geoheritage for the purpose of tourism. It has rich geological, geomorphological and hydrological diversity and geo-tourism potential, but has not yet developed enough destinations for this type of tourism. A major disadvantage for promotion of the geoheritage facilities is the basic infrastructure, the lack of information panels, media coverage and information centers for visitors. Cooperation with the local communities, tourism and non-governmental organizations is important for preserving and promoting the geoheritage. The first step in promoting the objects of the geoheritage 
is the engagement of several institutions through the preparation of studies on nature, generally at the entire territory of the Republic of Macedonia, as well as individual studies for specific facilities for the geoheritage, the main purpose of which is to implement their inventory. A concrete example of this issue is the study of the geodiversity and geoheritage in the Republic of Macedonia and other components of nature (biological and landscape diversity) in 2016. By making such studies, representative and unique objects of geoheritage are being promoted that are of great importance. They need to be edited and made accessible to visitors who want to see and expand their knowledge about their creation. This will involve a number of tourist activities that will contribute to the overall tourist promotion of this facility. However, it is necessary to put great emphasis on its protection, because with the increased tourist presence there is a possibility that the objects of the geoheritage will be endangered. For the promotion of the natural values of the country of great interest is the preparation of geotourism maps. It is also worth mentioning that the Republic of Macedonia is a member of the Western Balkans Geotourism Network. Through the websites www.exloringmacedonia.com and www.macedonia-timeless.com the natural beauties are affirmed of which the state is rich with and contribute to their greater popularization.

Through the presented three objects from the geoheritage, it is shown that the Republic of Macedonia is in a small percentage penetrated by the promotion of geotourism, but it possesses a great natural potential which should be appropriately regulated, promoted and protected to be inscribed in the geotourism tours. With the greater investment in this kind of tourism, to be further developed, the Republic of Macedonia will acquire a great economic benefit that will affect all sectors of its development.

\section{REFERENCES}

[1] Bell, S. Design for outdoor recreation, Taylor \& Francis, Abingdon, pp. 240, 2008.

[2] Dowling, R.K. Geotourism's Global Growth. Geoheritage, Springer-Verlag, vol. 3, . n ${ }^{\circ}$, pp. $1-13,2010$.

[3] Gray, M. Geodiversity: Valuing and Conserving Abiotic Nature. Chichester. U.K: John Wiley \& Sons., pp. 1-433, 2004.

[4] Gray, M. Geodiversity and Geoconservation: What, Why and How? George Wright Forum, vol. 22, ${ }^{\circ} 3$, pp. 4-12, 2005.

[5] JPPUP. Spatial plan of the Republic of Macedonia, Official Gazette of the Republic of Macedonia No. 4/96, 28/97, 18/99, 53/2001 and 45/2002), Skopje, pp. 102-108, 2004.

[6] Kolchakovski D. Physical Geography of the Republic of Macedonia; Skopje, pp. 1-273, 2004.

[7] Kolchakovski D. Recently evidenced localities in the Republic of Macedonia in the function of protecting geodiversity, Bulletin of Physical Geography, Skopje, n ${ }^{\circ}$ 7-8, pp.15-27, 2011.

[8] Kostovski J.V. Peshti Gorge, Bulletin of the Serbian Geographical Society, Belgrade, vol. XXXIV, ${ }^{\circ} 1,1956$.

[9] Manakovic D. Some relief forms in the valley of the river Babuna and Topolka with the Titoveleshka Valley, Yr. Proceedings of PMF, Skopje, n 15, pp. 87-139,1966.

[10] Newsome D, Dowling RK. Geotourism: the tourism of geology and landscape. Goodfellow Publishers, Oxford, pp. 1-20, 2010.

[11] Official Gazette no. 39, Law on the Proclamation of "Vevchani Springs" as a monument of nature, Skopje, pp. 2, 2012. 
[12] Sharples, C. Concepts and Principles of Geoconservation, Tasmanian Parks \& Wildlife Service, pp. 1-79, 2002.

[13] State Statistical Office; Environmental Statistics, Skopje, pp. 136, 2017.

[14] Study on geodiversity and geoheritage of the Republic of Macedonia and other components of nature (biological and landscape diversity), Ministry of Environment and Physical Planning, Skopje, pp. 1-503, 2016.

[15] Todorova A., Kolchakovski D., Dimitrovska O., Milevski I. Protection and presentation of the "Pillow Lava" site near the village of Miravci, Geographical Reviews, Skopje, no. 49, pp. 512, 2016.

[16] www.exloringmacedonia.com

[17] www.macedonia-timeless.com 